\title{
Reduction in hypercholesterolemia and risk of cardiovascular diseases by mixtures of plant food extracts: a study on plasma lipid profile, oxidative stress and testosterone in rats
}

\author{
By Doha A. Mohamed, Thanaa E. Hamed and Sahar Y. Al-Okbi * \\ Food Sciences and Nutrition Department, National Research Centre, Dokki, Cairo, Egypt \\ ( ${ }^{*}$ Corresponding author: S_Y_alokbi@ hotmail.com)
}

\section{RESUMEN}

Reducción de las enfermedades cardiovasculares e hipercolesterolemia por mezclas de extractos de plantas comestibles: un estudio del perfil lipídico, estrés oxidativo y testosterona en ratas.

El presente estudio fue dirigido a preparar y evaluar la influencia de dos mezclas de extractos de plantas comestibles sobre el perfil lipídico del plasma, estrés oxidativo y nivel de testosterona en ratas alimentadas con una dieta hipercolesterolemica. La salubridad de las mezclas de extractos estudiadas fue evaluada mediante la determinación de las funciones del hígado y del riñón. El contenido total de fenoles, tocoferoles, ácidos grasos, y materia insaponificable (UNSAP) fueron determinado en la mezclas de extractos. Las ratas fueron alimentadas con dietas hipercolesterolémica junto con una dosis oral diaria de (300 mg/kg de peso) cada mezcla I y II durante un mes y comparada con un control hipercolesterolémico y un control normal. Los resultados muestran que el contenido de $\alpha$-tocopherol fue 0.750 y $4.017 \mathrm{mg}, \gamma$-tocopherol fue $0.564 \mathrm{mg}$ y 0 y $\delta$-tocopherol fue $15.23 \mathrm{mg}$ y $0.634 \mathrm{mg} / 100 \mathrm{~g}$ de mezcla I y II, respectivamente. El contenido de fenoles en las mezcla I and II fue 36.74 y 23.72 g equivalentes de ácido gálico/100g de mezcla, respectivamente. La investigación por GLC de UNSAP reveló que el estigmasterol y el $\beta$-sitosterol fueron los principales fitoesteroles de las mezclas I y II, respectivamente seguido por el campesterol en ambos casos. El análisis por GLC de los ácidos grasos mostró que el ácido oleico fue el ácido graso mayoritario en ambas mezclas de extractos. Los resultados con animales de experimentación mostraron que la alimentación con dietas hipercolesterolémicas produce un incremento significativo en los lípidos totales, colesterol total (T-Ch), triglicéridos (TGs), colesterol en lipoproteínas de baja densidad (LDL-Ch), en las relaciones T-Ch/ HDL-Ch y TGs/HDL-Ch y malondialdehido (MDA) y una significativa reducción en el colesterol de las lipoproteínas de alta densidad (HDL-Ch), vitamina $E, \beta$-caroteno and testosterona. Las ratas alimentadas con dietas hipercolesterolémicas junto con mezclas I y II mostraron una mejora significativa del perfil lipídico del plasma comparado con el grupo control hypercholesterolémico. Esta mejora estuvo asociada con una significativa reducción del estrés oxidativo reflejado por la elevación de los niveles de antioxidantes en el plasma (vitamin E y $\beta$ carotene) y reducción de los niveles de MDA en plasma. Los niveles de testosterona en plasma aumentaron significativamente en ratas alimentadas con dietas hipercolesterolémicas junto con mezclas I y II en comparación con el control hipercolesterolémico. La testosterona del plasma mostró una correlación negativa significativa con los TGs y TGs/HDL-Ch en ratas control hipercolesterolémicas. Las mezclas de los extractos estudiados mostraron una completa salubridad hacia las funciones del hígado y el riñón. En conclusión las mez- clas mostraron una mejora del perfil lipídico del plasma, un significativo incremento en la testosterona, y un descenso del estrés oxidativo con una prometedora prevención de las enfermedades cardiovasculares y ateroesclerosis. El efecto anti-aterogénico de las mezclas de los extractos puede ser debida a la presencia de compuestos fenólicos, fitoesteroles, tocoferoles y ácidos grasos insaturados.

PALABRAS CLAVE: Estrés oxidativo - Hipercolesterolemia - Mezclas de extractos - Perfil lipídico - Testosterona.

\section{Summary}

Reduction in hypercholesterolemia and risk of cardiovascular diseases by mixtures of plant food extract: a study on plasma lipid profile, oxidative stress and testosterone in rats.

The present study was postulated to prepare and evaluate the influence of two plant food extract mixtures on plasma lipid profile, oxidative stress and testosterone levels in rats fed a hypercholesterolemic diet. The safety of the studied extract mixtures was evaluated through the determination of liver and kidney functions. The total phenolic contents, tocopherols, fatty acids and unsaponifiable matter (UNSAP) in the extract mixtures were determined. Rats fed a hypercholesterolemic diet were given a daily oral dose (300 mg/kg rat body weight) of either mixture I or II for a month and compared with a control hypercholesterolemic group and a normal control group. Results showed that $\alpha$-tocopherol was 0.750 and 4.017 $\mathrm{mg}, \gamma$-tocopherol was $0.564 \mathrm{mg}$ and 0 and $\delta$-tocopherol was $15.23 \mathrm{mg}$ and $0.634 \mathrm{mg} / 100 \mathrm{~g}$ for mixtures I and II, respectively. The phenolic contents in mixtures I and II were 36.74 and $23.72 \mathrm{~g}$ gallic acid equivalent/100g mixture, respectively. The GLC investigation of UNSAP revealed that stigmasterol and $\beta$-sitosterol were the major phytosterols in mixtures I and II, respectively followed by campesterol in both. The GLC analysis of the fatty acids showed that oleic acid was the major fatty acid in both extract mixtures. Results from the animal experiment showed that feeding a hypercholesterolemic diet produced a significant increase in total lipids, total cholesterol (T-Ch), triglycerides (TGs), low density lipoprotein cholesterol (LDL$\mathrm{Ch}$ ), T-Ch/HDL-Ch, TGs/HDL-Ch and malondialdehyde (MDA) and a significant reduction in high density lipoprotein cholesterol (HDL-Ch), vitamin E, $\beta$-carotene and testosterone. Rats fed a hypercholesterolemic diet and given mixture I or II showed significant improvements in plasma lipid profile compared to the hypercholesterolemic control group. This improvement was associated with a significant reduction in oxidative stress reflected by an elevation in plasma levels of antioxidants (vitamin $\mathrm{E}$ and $\beta$-carotene) and a reduction in plasma MDA levels. The plasma level of testosterone increased significantly 
in the rats fed the hypercholesterolemic diet and given mixture I or II compared to the hypercholesterolemic control. Plasma testosterone showed a significant negative correlation with plasma TGs and TGs/HDL-Ch in the hypercholesterolemic control rats. The studied extract mixtures showed complete safety towards liver and kidney functions. In conclusion the tested extract mixtures showed an improvement in the plasma lipid profile, a significant increase in testosterone and a decrease in oxidative stress with promising prevention of atherosclerosis and cardiovascular diseases. The antiatherogenic effect of the extract mixtures may be due to the presence of phenolic compounds, phytosterols, tocopherols and unsaturated fatty acids.

KEY-WORDS: Extract mixtures - Hypercholesterolemia - Lipid profile - Oxidative stress - Testosterone.

\section{INTRODUCTION}

Cardiovascular diseases (CVD) including coronary heart disease and stroke are the leading cause of mortality in both developed and developing countries, accounting for roughly $20 \%$ of all worldwide deaths per year (Thomas and Rich, 2007). Therefore, hypercholesterolemia and its associated CVD represent one of the greatest worldwide economic, social and medical challenges that we are facing now (Olshansky et al., 2005). The large majority of epidemiological studies have demonstrated that elevated plasma triglycerides and/or reduced plasma HDL-Ch concentrations are associated with increased cardiovascular risk (Poli et al., 2008). An abnormal ratio of triglycerides to HDL-Ch indicates an atherogenic lipid profile and a risk for the development of coronary diseases (da Luz et al., 2008). Changes in endothelial function play an important role in the pathophysiology of atherosclerosis and there is evidence suggesting that interventions to improve endothelial function may have an impact on the progression and the risk of cardiovascular events (Thorand et al., 2006). Few data are currently available on the correlation between plasma testosterone levels and coronary artery disease. Androgen in general and testosterone in particular may have some protective effects on the cardiovascular system through their metabolic and direct effect on the human vasculature (Rosano et al., 2005). Patients with coronary artery disease (CAD) have lower testosterone levels than healthy control patients, suggesting that low plasma testosterone may be involved in the increased risk of CAD in men (Rosano et al., 2007). Over the last three decades, it has become apparent that testosterone plays a significant role in lipid metabolism and glucose homeostasis. Lower total testosterone predicts a higher incidence of the metabolic syndrome. There is evidence that hypotestosteronemia should be an element in the definition of the metabolic syndrome since low levels of testosterone are associated with or predict the development of such a syndrome. The metabolic syndrome is a clustering of risk factors predisposing to diabetes mellitus type 2, atherosclerosis and cardiovascular morbidity and mortality. The main components of the syndrome are visceral obesity, insulin resistance, glucose intolerance, raised blood pressure and dyslipidemia (elevated triglycerides, low levels of high-density lipoprotein cholesterol), and a pro-inflammatory and thrombogenic state (Saad and Gooren, 2009). The effects of physiological doses of testosterone seem to have less impact on the parameters of lipid metabolism. However, supraphysiological levels of testosterone can lower HDL levels (Schubert and Jockenhövel, 2010). The relationship between androgen deficiency and atherosclerosis is complex, poorly understood, and remains controversial. Studies in animals and humans suggest that androgen deficiency is associated with increased TGs, T-Ch, and LDLCh. Although the effects of androgen deficiency on HDL-Ch remains controversial, recent data suggest reduced levels and androgen therapy are associated with increased levels of HDL-Ch and may improve reverse cholesterol transport. Furthermore, androgen treatment of hypogonadal men significantly improved lipid profiles. Emerging data indicate that androgens play an important role in lipid metabolism. Androgen treatment results in a favorable lipid profile, suggesting that androgens may provide a protective effect against the development and/or progression of atherosclerosis (Traish et al., 2009).

Oxidative stress plays an important role in the initiation and progression of atherosclerosis by stimulating inflammation and promoting cytokine production (Fernández-Robredo et al., 2008). Diet plays an important role in the maintenance of optimal cardiovascular health (Dauchet et al., 2009). Consumption of fruits and vegetables is associated with lower concentrations of total and low-density lipoprotein cholesterol and with a lowered incidence of CVD (Mirmiran et al., 2009). This effect has been ascribed, in part to the antioxidants; polyphenols, tocopherols and carotenoids in plant-based foods. Plant foods rich in antioxidant molecules have received a growing interest because they delay the oxidative degradation of lipids (Nicolle et al., 2004). Phenolic compounds and flavonoids have pharmacological properties such as antioxidant, antithrombotic and hypolipidemic effects (Son and Lewis, 2002). Because lifestyle related diseases such as atherosclerosis progress gradually due to unfavorable dietary habits, an improvement of daily nutritional intake is thought to prevent the pathogenesis of such diseases. Examples of plants foods that may possess antioxidant and hypolipidemic effects are tomato and carrots which are rich in carotenoids (Fuhrman et al., 1997), wheat germ and rice bran oil which are rich in tocopherols, phytosterols, unsaturated fatty acids and other oil soluble active constituents (Ardiansyah et al., 2006; Khatoon and Gopalakrishna, 2004; Wang and Johnson, 2001; Rustan et al., 1993). Thyme and celery seed contain high levels of phenolic compounds (Naemura et al., 2008; Momin and Nair, 2002). If bioactive extracts from the abovementioned plant foods were mixed together, they may act synergistically as powerful anti atherogenic and hypocholesterolemic nutraceuticals. The objective of the present study was to prepare two mixtures of the aforementioned plant food extracts and 
evaluate their effects on plasma lipid profiles, oxidative stress and testosterone in rats fed a hypercholesterolemic diet. The correlation between testosterone levels and plasma lipids was studied as a marker of atherosclerosis risk. The safety of the tested extract mixtures was studied. Fatty acids, phytosterols, tocopherols and total phenolic contents of the studied plants extract mixtures were also assessed.

\section{MATERIALS AND METHODS}

\subsection{Materials}

\section{Plant materials}

Fresh tomato and carrot, thyme herb and celery seeds were purchased from local markets, while wheat germ was obtained from South Cairo and Giza Milling Co. Rice bran (Sakha 101, short grain) was stabilized after milling by heating at $125^{\circ} \mathrm{C}$ for $15 \mathrm{~min}$.

\section{Animals}

Male Sprague Dawley rats of 86 to $110 \mathrm{~g}$. body weight were used in the present study. The animals were kept individually in stainless steel cages; water and food were given ad-libtium.

\subsection{Methods}

\section{Preparation of plant materials}

Fresh tomato and carrot were washed with tap water and cut into small pieces. All prepared and purchased plant materials were dried separately in an air-circulated oven at $40^{\circ} \mathrm{C}$ to complete dryness, and then they were reduced into powder for use in the extraction.

\section{Preparation of plant extracts}

The dried powder of tomato and carrot were separately placed in a continuous extraction apparatus and subjected to extraction using acetone for the extraction of carotenoids including lycopenes. Wheat germ and rice bran were subjected to continuous extraction separately using petroleum ether $\left(40-60^{\circ} \mathrm{C}\right)$ to prepare the oil. Thyme herb and celery seeds were separately subjected to crude extraction using methanol in a continuous extraction apparatus. The solvent of each extract was completely removed by evaporation under reduced pressure at a temperature not exceeding $40^{\circ} \mathrm{C}$. All extracts were kept in deepfreeze until used.

\section{Preparation of extract mixtures}

The crude methanol extract of thyme herb, wheat germ oil and the acetone extract of carrot were mixed to prepare mixture I. The mixture of crude methanol extract of celery seeds, rice bran oil and the acetone extract of tomato was designated as mixture II.

\section{Determination of tocopherols}

Tocopherols ( $\alpha, \gamma$ and $\delta$ ) were determined according to the method of Amaral et al. (2005). Samples from each extract mixture ( 300mg) were accurately weighed in glass screw cap tubes and homogenized with $2 \mathrm{ml}$ ethanol by vortex mixing (1 $\mathrm{min}), 100 \mu \mathrm{l}$ of butylated hydroxy toluene (10 $\mathrm{mg} / \mathrm{ml}$ ) was added for protection from oxidation. Subsequently, $4 \mathrm{ml}$ hexane was added and again vortex mixed for $1 \mathrm{~min}$. Two $\mathrm{ml}$ saturated $\mathrm{NaCl}$ aqueous solution was added, the mixture was homogenized (1 min), centrifuged (2 min, 5000g) and the clear upper layer was carefully transferred to another glass screw cap tube. The sample was re-extracted twice with hexane. The combined extracts were dried under a nitrogen stream, at room temperature. The samples were transferred to microcentrifuge tubes with $1.5 \mathrm{ml}$ of hexane and finally, dehydrated with anhydrous sodium sulphate. The extract was centrifuged (10000g, $20 \mathrm{sec}$.), transferred into a dark injection vial and analyzed by HPLC.

\section{HPLC analysis}

An HPLC/Agilent model, Agilent $1100 \mathrm{G}$ 1311A Quat pump, G1322A Degasser, G 1329A Autosampler, G 1330A Chiller, G 1316A column compartment, fluorescence detector PC and Chemstation software were used along with an SI $(150 \times 4.6 \mathrm{~mm})$ column. The wave length of excitation was at $290 \mathrm{~nm}$ and emission at $330 \mathrm{~nm}$. The mobile phase was a mixture of hexane and isopropanol (99:1, v/v), flow rate: $1 \mathrm{ml} / \mathrm{min}$. The concentrations of $\alpha, \gamma$ and $\delta$-tocopherols in the samples were obtained by comparing their peak areas with the peak area of standards in relation to concentration.

\section{Determination of total phenolic contents in extract mixtures}

Total phenolics were determined colorimetric in the extract mixtures using the Folin-Ciocalteu reagent (Singleton and Rossi, 1965). Absorbance was measured at $765 \mathrm{~nm}$ using UVPC spectrophotometer. The total phenolic content was expressed as gallic acid equivalent (GAE) in grams per 100 grams.

\section{Assessment of fatty acids, hydrocarbons and phytosterol contents in extract mixtures}

The unsaponifiable fraction and fatty acid methyl esters of the studied extract mixtures were prepared according to A.O.A.C (2000) to be subjected to the GLC analysis of fatty acids, hydrocarbons and phytosterols.

The unsaponifiable fraction was analyzed by GLC adopting the following conditions: Column: $10 \%$ OV- 
101 packed column; Stationary phase: Chromosorb W-HP; Detector temperature: $290^{\circ} \mathrm{C}$; Injector temperature, $28^{\circ} \mathrm{C}$; Carrier gas $\mathrm{N}_{2}$; flow-rate $30 \mathrm{ml} /$ min; air flow-rate: $300 \mathrm{ml} / \mathrm{min}$; $\mathrm{H}_{2}$ Flow-rate $30 \mathrm{ml} /$ min; Detector FID; Chart speed: $0.5 \mathrm{~cm} / \mathrm{min}$; Oven program: Initial temperature, $70^{\circ} \mathrm{C}$; Final temperature, $270^{\circ} \mathrm{C}$; programmed $4^{\circ} \mathrm{C} / \mathrm{min}$ for $35 \mathrm{~min}$ at $270^{\circ} \mathrm{C}$, total time, $85 \mathrm{~min}$. The identification of hydrocarbons and sterol contents of the unsaponifiable matter was carried out by comparison of their retention times with co-injected authentic reference compounds. Quantification was based on peak area integration.

The analysis by GLC of the methyl ester was made according to the following conditions: Stationary phase: $10 \%$ diethylene glycosuccinate (DEGS) packed column; oven temperature, $170^{\circ} \mathrm{C}$; detector temperature, $300^{\circ} \mathrm{C}$; injector temperature, $250^{\circ} \mathrm{C}$; Carrier gas, $\mathrm{N}_{2}$; flow-rate, $30 \mathrm{ml} / \mathrm{min}$; air flowrate, $350 \mathrm{ml} / \mathrm{min} ; \mathrm{H}_{2}$ flow-rate, $350 \mathrm{ml} / \mathrm{min}$; detector, FID; Chart speed, $2 \mathrm{~cm} / \mathrm{min}$. Identification of the fatty acid methyl ester was carried out by the direct comparison of the retention times of each of the separated compounds with authentic samples of the fatty acid methyl esters analyzed under the same conditions. Quantification was based on peak area integration.

\section{Preparation of dosage form}

Extract mixtures I and II were dispersed separately in water using gum acacia to be given orally to rats. For the control, the vehicle was prepared by dissolving the same amount of gum acacia in water.

\section{Preparation of diets}

Balanced (control) and hypercholesterolemic diets were prepared (Table 1). The hypercholesterolemic diet was designed in a similar way to that reported by Zulet et al. (1999), although with some modifications.
The hypercholesterolemic diet prepared by Zulet et al. (1999) contained $20 \%$ casein, $25 \%$ coconut oil, $1 \%$ cholesterol and $0.5 \%$ cholic acid. The hypercholesterolemic diet prepared in the present study contained $12.5 \%$ casein, $20 \%$ coconut oil, $1 \%$ cholesterol and $0.25 \%$ cholic acid as shown in Table 1. Salt mixture and vitamin mixture were prepared according to Briggs and Williams (1963) and Morcos (1967), respectively. Oil soluble vitamins were given orally in a dose of $0.1 \mathrm{ml} /$ rat per week.

\section{Design of the animal experiment}

Twenty-four rats were divided into four groups of 6 rats each. The first was the normal group where rats were received a balanced diet throughout the study period (one month), while group two was the hypercholesterolemic group, where rats were fed a hypercholesterolemic diet throughout the study period. In group three and four, rats were fed hypercholesterolemic diet with simultaneous administration of a daily oral dose of extract mixtures I and II respectively (300 $\mathrm{mg} / \mathrm{kg}$ rat body weight). During the experiment, body weight and food intake were recorded once a week. At the end of the study, total food intake, body weight gain and food efficiency ratio (Body weight gain/total food intake) were calculated. Blood samples were collected from all rats after an overnight fast for the determination of total plasma lipids (Toro and Ackerman, 1975), T-Ch (Watson, 1960), HDL-Ch (Burstein et al., 1980), LDL-Ch (Gerard and Gerald, 1981) and TGs (Megraw et al., 1979). T-Ch/HDL$\mathrm{Ch}$ ratio and $\mathrm{TGs} / \mathrm{HDL}-\mathrm{Ch}$ ratio were calculated. Plasma malondialdehyde was determined as an indicator of lipid peroxidation (Satoh, 1978). Plasma levels of vitamin $E$ and $\beta$-carotene were assessed according to the methods of Desai and Machlin (1985) and Neeld and Pearson (1963) respectively. Also plasma levels of testosterone were determined

Table 1

Composition of different experimental diets $(\mathrm{g} / 100 \mathrm{~g})$

\begin{tabular}{lcc}
\hline Ingredients & Balanced diet Control & Hypercholesterolemic diet \\
\hline Casein & $12.5^{\star}$ & $12.5^{*}$ \\
Corn oil & 10 & - \\
Coconut oil & - & 20 \\
Sucrose & 23.3 & 20.52 \\
Starch & 46.7 & 41.23 \\
Salt mix. & 3.5 & 3.5 \\
Vit. mix. & 1 & 1 \\
Fiber & 3 & - \\
Cholesterol & - & 1 \\
Cholic acid & - & 0.25 \\
\hline
\end{tabular}

*12.5 g casein has been estimated to contain $10 \mathrm{~g}$ protein (AOAC, 1995). 
in the samples using the ELISA technique (Tietz, 1995). The safety of plant extracts was studied through the evaluation of liver and kidney functions. Plasma levels of creatinine (Houot, 1985) and urea (Fawcett and Scott, 1960) were determined as indicators of kidney function, while the activities of aspartate transaminase (AST) and alanine transaminase (ALT) (Reitman and Frankel, 1957) were determined as indicators of liver function.

\section{Statistical analysis}

The results of the animal experiments were expressed as the Mean \pm SE and they were analyzed statistically using the one-way analysis of variance ANOVA followed by Duncan's test. Pearson correlation was applied to study the correlation between plasma testosterone and different plasma lipid parameters. In all cases $p<0.05$ was used as the criterion of statistical significance.

\section{RESULTS}

The tocopherols and total phenolic contents of the extract mixtures shown in Table (2) clarified that alpha-tocopherol was 0.750 and $4.017 \mathrm{mg} / 100 \mathrm{~g}$ of mixture I and II, respectively. Gamma-tocopherol was present only in mixture I as $0.564 \mathrm{mg} / 100 \mathrm{~g}$. Mixture I showed higher contents of $\delta$-tocopherol $(15.23 \mathrm{mg} / 100 \mathrm{~g})$, than mixture II $(0.634 \mathrm{mg} / 100 \mathrm{~g})$. The studied extract mixtures revealed high percentages of total phenolic compounds, which are present at 36.74 and $23.72 \mathrm{~g}$ GAE/100g in mixtures I and II, respectively.

Tables (3) and (4) show the fatty acids and unsaponifiable matter in the extract mixtures, respectively. The results of the total fatty acids analysis revealed that oleic acid was the major unsaturated fatty acid in both extract mixtures; it was present at $64.5 \%$ and $66.7 \%$ of the total fatty acids in mixtures I and II, respectively, while palmitic acid was the major saturated fatty acid in the two mixtures (15.4\% and $17.9 \%$ in mixtures I and II, respectively). A GLC investigation of the unsaponifiable matter showed the presence of stigmasterol $(2.6 \%$ of unsaponifiable matter) in mixture I and $\beta$-sitosterol $(2.6 \%)$ in mixture II. Campesterol was present in both extract mixtures as $2.2 \%$ in mixture I and $2.1 \%$ in mixture II. Total phytosterol was more or less equal in the two mixtures. The major hydrocarbon was C23 in mixture I (16.91\%) and C22 in mixture II (11.31\%).

Table 2

Tocopherols and total phenolic contents of extract mixtures

\begin{tabular}{lcc}
\hline Ingredients & Extract mixture I & Extract mixture II \\
\hline Tocopherols (mg/100g mixture): & & 4.017 \\
$\alpha$ - tocopherol & 0.750 & 0.0 \\
$\gamma$ - tocopherol & 0.564 & 0.634 \\
$\delta$ - tocopherol & 15.23 & 23.72 \\
\hline Total phenolic compounds (g GAE*/100g mixture) & 36.74 & \\
\hline
\end{tabular}

${ }^{*}$ GAE: Gallic acid equivalent

Table 3

Fatty acids contents of the different extract mixtures (as percentage of total fatty acids)

\begin{tabular}{lcc}
\hline Fatty acids & Extract mixture I & Extract mixture II \\
\hline C14 : & 0.29 & 0.53 \\
C16 : & 15.40 & 17.90 \\
C18 : & 64.50 & 66.70 \\
C18 : 2 & 0.18 & 1.18 \\
C18 : 3 & - & - \\
C20 : 0 & 0.48 & 0.03 \\
C22 : 0 & 1.41 & 1.43 \\
Total saturated fatty acids & 17.58 & 19.89 \\
Total unsaturated fatty acids & 64.68 & 67.88 \\
\hline
\end{tabular}


Table 4

GLC analysis of unsaponifiable matter of the different extract mixtures (as percentages of total unsaponifiable matter)

\begin{tabular}{|c|c|c|}
\hline Hydrocarbon and sterols & Extract mixture I & Extract mixture II \\
\hline \multicolumn{3}{|l|}{ Hydrocarbon } \\
\hline $\mathrm{C9}$ & - & 0.03 \\
\hline C11 & 0.38 & - \\
\hline $\mathrm{C} 13$ & 1.19 & 0.10 \\
\hline $\mathrm{C} 14$ & 0.25 & 1.63 \\
\hline $\mathrm{C} 15$ & - & 4.15 \\
\hline $\mathrm{C} 16$ & 0.94 & - \\
\hline $\mathrm{C} 17$ & 0.42 & - \\
\hline C18 & 2.42 & 0.67 \\
\hline C19 & 1.76 & 2.17 \\
\hline $\mathrm{C} 20$ & 2.55 & 1.49 \\
\hline $\mathrm{C} 21$ & 6.54 & 4.55 \\
\hline $\mathrm{C} 22$ & - & 11.31 \\
\hline $\mathrm{C} 23$ & 16.91 & 3.53 \\
\hline $\mathrm{C} 24$ & 4.21 & 5.81 \\
\hline Total hydrocarbon & 37.57 & 35.44 \\
\hline \multicolumn{3}{|l|}{ Phytosterols } \\
\hline Campesterol & 2.2 & 2.1 \\
\hline Stigmasterol & 2.6 & - \\
\hline$\beta$-Sitosterol & - & 2.6 \\
\hline Total phytosterols & 4.8 & 4.7 \\
\hline
\end{tabular}

Concerning the animal experiment, non significant differences were observed between different groups in final body weight, body weight gain and food efficiency ratio (Table 5). Total food intake was significantly higher in the groups given mixtures I and II compared to the two control groups.

The plasma levels of total lipids, T-Ch, LDL-Ch, TGs and the ratios of TGs/HDL-Ch and T-Ch/HDL-Ch of the control hypercholesterolemic rats showed significant increases, while the plasma levels of HDL-Ch showed significant reductions compared to the different groups (Table 6). Control hypercholesterolemic rats showed elevations in oxidative stress reflected by reductions in antioxidant status (plasma vitamin $E$ and $\beta$-carotene) and significant elevations in plasma MDA levels as an indicator of lipid peroxidation compared to all other groups. The plasma level of testosterone was reduced significantly in control hypercholesterolemic rats compared with the different groups.

Oral administration of mixtures I and II showed significant improvements in plasma lipid profile, antioxidant status, lipid peroxidation parameters and testosterone levels when compared with hypercholesterolemic rats given no extracts (Table 6).
Only the plasma TG, $\beta$-carotene and vitamin $E$ levels of the test groups matched that of the normal control while all the other parameters of the test groups, although improved, were still significantly different from the normal rats. The Plasma malondialdehyde level was reduced significantly in rats given mixtures I and II by $26 \%$ and $12 \%$ respectively compared with the control hypercholesterolemic rats. The plasma levels of $\beta$-carotene and vitamin $E$ were elevated in rats given mixture $\mathrm{I}$ by $10 \%$ and $11 \%$ and those that received mixture II by 9 and $8 \%$, respectively compared with the control hypercholesterolemic rats. In addition, the plasma levels of testosterone were significantly higher in hypercholesterolemic rats given mixtures I and II by 35 and 33\%, respectively compared with the control hypercholesterolemic rats.

The correlation study of the hypercholesterolemic control showed a significant negative relationship between plasma testosterone level and total plasma lipids $(r=-0.7883)$, TGs $(r=-0.9715)$, LDL-Ch ( $r=-0.7947)$, T-Ch/HDL-Ch $(r=-0.6052)$ and the TGs/HDL-Ch ratio $(r=-0.7265)$, while the testosterone level correlated positively with HDLCh $(r=0.52728)$. 
Table 5

Nutritional parameters of different experimental groups

\begin{tabular}{lcccc}
\hline Parameters & $\begin{array}{c}\text { Normal control } \\
\mathbf{n}=6\end{array}$ & $\begin{array}{c}\text { Hypercholesterolemic } \\
\text { control } \mathbf{n}=6\end{array}$ & $\begin{array}{c}\text { Extract mixture I } \\
\mathbf{n}=6\end{array}$ & $\begin{array}{c}\text { Extract mixture II } \\
\mathbf{n}=6\end{array}$ \\
\hline Initial body weight(g) & $95.3 \pm 4.112^{\mathrm{a}}$ & $95.3 \pm 3.451^{\mathrm{a}}$ & $95.5 \pm 2.668^{\mathrm{a}}$ & $95.5 \pm 2.172^{\mathrm{a}}$ \\
Final body weight $(\mathrm{g})$ & $220.5 \pm 8.437^{\mathrm{a}}$ & $229.5 \pm 1.765^{\mathrm{a}}$ & $221.5 \pm 11.108^{\mathrm{a}}$ & $226.3 \pm 12.228^{\mathrm{a}}$ \\
Body weight gain $(\mathrm{g})$ & $125.2 \pm 7.666^{\mathrm{a}}$ & $134.2 \pm 3.757^{\mathrm{a}}$ & $126.0 \pm 9.525^{\mathrm{a}}$ & $130.8 \pm 11.205^{\mathrm{a}}$ \\
T. Food intake (g) & $507.3 \pm 18.15^{\mathrm{a}}$ & $519.2 \pm 9.199^{\mathrm{a}}$ & $567.0 \pm 18.944^{\mathrm{b}}$ & $549.7 \pm 6.163^{\mathrm{b}}$ \\
Food efficiency ratio & $0.247 \pm 0.009^{\mathrm{a}}$ & $0.258 \pm 0.007^{\mathrm{a}}$ & $0.221 \pm 0.003^{\mathrm{a}}$ & $0.238 \pm 0.005^{\mathrm{a}}$ \\
\hline
\end{tabular}

In each row the same letter means non significant difference while different letters mean significant differences att 0.05 probability.

Table 6

Plasma parameters of hypercholesterolemic rats fed different experimental diets

\begin{tabular}{lcccc}
\hline Parameters & $\begin{array}{c}\text { Normal control } \\
\mathbf{n}=\mathbf{6}\end{array}$ & $\begin{array}{c}\text { Hypercholesterolemic } \\
\text { control } \mathbf{n}=6\end{array}$ & $\begin{array}{c}\text { Extract mixture I } \\
\mathbf{n}=6\end{array}$ & $\begin{array}{c}\text { Extract mixture II } \\
\mathbf{n}=6\end{array}$ \\
\hline Total lipids $(\mathrm{mg} / \mathrm{dl})$ & $386.7 \pm 6.667^{\mathrm{a}}$ & $775.0 \pm 11.762^{\mathrm{c}}$ & $583.3 \pm 8.819^{\mathrm{b}}$ & $609.5 \pm 8.808^{\mathrm{b}}$ \\
T-Ch $(\mathrm{mg} / \mathrm{dl})$ & $84.5 \pm 3.239^{\mathrm{a}}$ & $207.8 \pm 4.707^{\mathrm{c}}$ & $167.2 \pm 3.390^{\mathrm{b}}$ & $178.2 \pm 3.487^{\mathrm{b}}$ \\
HDL-Ch $(\mathrm{mg} / \mathrm{dl})$ & $41.1 \pm 0.737^{\mathrm{c}}$ & $23.6 \pm 0.757^{\mathrm{a}}$ & $33.2 \pm 1.078^{\mathrm{b}}$ & $31.5 \pm 1.057^{\mathrm{b}}$ \\
LDL-Ch $(\mathrm{mg} / \mathrm{dl})$ & $20.7 \pm 0.665^{\mathrm{a}}$ & $103.8 \pm 3.487^{\mathrm{c}}$ & $72.8 \pm 2.414^{\mathrm{b}}$ & $71.2 \pm 2.414^{\mathrm{b}}$ \\
TCh/HDL-Ch ratio & $2.06 \pm 0.102^{\mathrm{a}}$ & $8.83 \pm 0.282^{\mathrm{c}}$ & $5.07 \pm 0.227^{\mathrm{b}}$ & $5.67 \pm 0.131^{\mathrm{d}}$ \\
TGs $(\mathrm{mg} / \mathrm{dl})$ & $93.5 \pm 1.356^{\mathrm{a}}$ & $101.7 \pm 0.964^{\mathrm{b}}$ & $96.8 \pm 1.830^{\mathrm{a}}$ & $95.7 \pm 1.684^{\mathrm{a}}$ \\
TGs/HDL-Ch ratio & $2.3 \pm 0.059^{\mathrm{a}}$ & $4.3 \pm 0.158^{\mathrm{c}}$ & $2.9 \pm 0.095^{\mathrm{b}}$ & $3.1 \pm 0.148^{\mathrm{b}}$ \\
MDA $(\mathrm{nmol} / \mathrm{ml})$ & $4.87 \pm 0.281^{\mathrm{a}}$ & $7.82 \pm 0.214^{\mathrm{d}}$ & $5.77 \pm 0.313^{\mathrm{b}}$ & $6.87 \pm 0.234^{\mathrm{c}}$ \\
Testosterone $(\mathrm{nmol} / \mathrm{l})$ & $1.53 \pm 0.071^{\mathrm{c}}$ & $0.82 \pm 0.036^{\mathrm{a}}$ & $1.11 \pm 0.058^{\mathrm{b}}$ & $1.09 \pm 0.058^{\mathrm{b}}$ \\
$\beta$-carotene $(\mu \mathrm{g} / \mathrm{dl})$ & $2.04 \pm 0.142^{\mathrm{b}}$ & $1.76 \pm 0.09^{\mathrm{a}}$ & $1.93 \pm 0.063^{\mathrm{b}}$ & $1.95 \pm 0.041^{\mathrm{b}}$ \\
Vitamin $\mathrm{mg} / \mathrm{dl})$ & $1.44 \pm 0.05^{\mathrm{b}}$ & $1.3 \pm 0.034^{\mathrm{a}}$ & $1.42 \pm 0.022^{\mathrm{b}}$ & $1.40 \pm 0.030^{\mathrm{ab}}$ \\
\hline
\end{tabular}

In each row the same letter means non significant difference while different letters mean significant differences at at $0.05 p r o b a b i l i t y$.

The plasma levels of creatinine and urea as indicators of kidney function showed non-significant changes in all groups (Table 7). Also plasma activity of AST and ALT as indicator of liver function showed non-significant changes in all the studied groups. This revealed the complete safety of the studied extract mixtures.

\section{DISCUSSION}

Antioxidants play an important role in the body's defence system against reactive oxygen species (ROS) (Gutteridge and Halliwell, 2000). There is growing scientific evidence associating antioxidantrich diets with a lower incidence of cardiovascular disease, cancers, and age-related degenerative processes (Kaliora and Dedoussis, 2007). The main dietary antioxidants in foods include vitamins (vitamin C and E), carotenoids, phytosterols and a wide variety of antioxidant phytochemicals such as simple phenolic compounds, flavonoid glycosides and polyphenols (Kris-Etherton et al., 2002; Pellegrini et al., 2003; Stanner et al., 2004; Guo and Xu, 2005).

The present study was postulated to prepare two plant food extract mixtures. The tocopherols, phenolic compounds, phytosterols and the fatty acid contents of the two mixtures were determined. The study aimed at evaluating the effect of the administration of the extract mixtures on plasma lipid profile, oxidative stress and testosterone levels in rats fed a hypercholesterolemic diet. These two mixtures contained rice bran oil or wheat germ oil as a source of tocopherols, phytosterols and unsaturated fatty acids. The mixtures also contained an acetone extract of carrot or tomato as a source of carotenoids and the crude methanol extract of thyme or celery seeds as a source of phenolic compounds.

Hypercholesterolemic control rats showed a significant elevation of total lipids, total cholesterol, triglycerides LDL-cholesterol and the ratios of TGs/ HDL-Ch and T-Ch/HDL-Ch, which was accompanied by a significant reduction in the plasma levels of HDL-cholesterol. These changes in plasma lipid 
Table 7

Liver and kidney function of different experimental groups

\begin{tabular}{lcccc}
\hline Parameters & $\begin{array}{c}\text { Normal control } \\
\mathbf{n}=6\end{array}$ & $\begin{array}{c}\text { Hypercholesterolemic } \\
\text { control } \mathbf{n}=6\end{array}$ & $\begin{array}{c}\text { Extract mixture I } \\
\mathbf{n}=6\end{array}$ & $\begin{array}{c}\text { Extract mixture II } \\
\mathbf{n}=6\end{array}$ \\
\hline Creatinine $(\mu \mathrm{mol} / \mathrm{l})$ & $61.45 \pm 1.665^{\mathrm{a}}$ & $61.87 \pm 1.618^{\mathrm{a}}$ & $61.04 \pm 1.014^{\mathrm{a}}$ & $61.52 \pm 0.821^{\mathrm{a}}$ \\
Urea $(\mathrm{mmol} / \mathrm{l})$ & $5.14 \pm 0.115^{\mathrm{a}}$ & $5.31 \pm 0.118^{\mathrm{a}}$ & $5.16 \pm 0.116^{\mathrm{a}}$ & $5.12 \pm 0.055^{\mathrm{a}}$ \\
$\mathrm{AST}^{*}(\mathrm{U} / \mathrm{l})$ & $62.66 \pm 1.022^{\mathrm{a}}$ & $62.83 \pm 0.601^{\mathrm{a}}$ & $62.50 \pm 0.619^{\mathrm{a}}$ & $62.67 \pm 0.422^{\mathrm{a}}$ \\
$\mathrm{ALT}^{\star}(\mathrm{U} / \mathrm{l})$ & $15.45 \pm 0.178^{\mathrm{a}}$ & $15.6 \pm 0.277^{\mathrm{a}}$ & $15.58 \pm 0.242^{\mathrm{a}}$ & $15.75 \pm 0.159^{\mathrm{a}}$ \\
\hline
\end{tabular}

In each row the same letter means non significant difference while different letters mean significant differences att 0.05 probability.

${ }^{*}$ AST : Aspartate transaminase. *ALT : Alanine transaminase.

profile in hypercholesterolemic rats in the study are in agreement with those reported previously (Yang et al., 2006). The elevation in the ratios of TGs/HDL-Ch and T-Ch/HDL-Ch observed in hypercholesterolemic control rats are believed to be important risk factors for atherosclerosis (atherogenic lipid profile) as reported by Yang et al. (2006) and da Luz et al. (2008). Administration of the studied extract mixtures produced a significant reduction in these ratios compared with hypercholesterolemic control rats but still significantly higher than normal rats. So the studied extract mixtures possess significant antiatherogenic properties.

Hypercholesterolemia induces oxidative stress by causing a reduction in the enzymatic antioxidant defense potential of tissues and the generation of oxygen free radicals such as superoxide anions. As a result of these metabolic events, peroxidation reactions are accelerated, leading to cellular injury and atherosclerosis (Gokkusu and Mostafazadeh, 2003). It was reported previously that oxidative stress has been implicated in many disease states including atherosclerosis and heart diseases (Shah et al., 2007). An imbalance between free radical production and antioxidant levels leads to elevated oxidative stress. The elevation of oxidative stress is obvious in hypercholesterolemic control rats in the present study which was reflected by a reduction in vitamin $E$ and $\beta$-carotene levels as an indicator to antioxidant status and by the elevation of MDA levels an an indicator of lipid peroxidation. Oral administration of both extract mixtures prevented the elevation of oxidative stress through the reduction of lipid peroxidation and the elevation of antioxidant status.

Hypercholesterolemia was accompanied by a reduction in testosterone levels in the control hypercholesterolemic rats in our study. These results are in agreement with the results of Ramirez et al. (2000). Testosterone correlated inversely with triglycerides and TGs/HDL-Ch ratio, while it correlated positively with HDL-Ch. These results suggest that the testosterone level inversely correlated with all the parameters responsible for cardiovascular diseases. So the reduction in testosterone levels in hypercholesterolemic rats could be considered as one of the atherogenic parameters, which agreed with the results of Rosano et al. (2007). The administration of any of the studied extract mixtures significantly elevated testosterone levels in rats fed a hypercholesterolemic diet.

It is worthy to mention that testosterone is synthesized from cholesterol that is mostly derived from the plasma. Much of the cholesterol in the adrenal and testes is esterified and stored, waiting for stimulation of hormonal synthesis (Granner, 1996). Despite the high level of plasma cholesterol in hypercholesterolemic control rats in the present study, a severe reduction in plasma testosterone was noticed which may be related to a disorder of cholesterol esterification in such a case. Studies in animals and humans suggest that androgen deficiency is associated with increased TGs, T-Ch, and LDL-Ch. The effects of androgen deficiency on HDL-Ch remains controversial, however recent data suggest a reduced level. The normalization of plasma testosterone provides a protective effect against the development and/or progression of atherosclerosis (Traish et al., 2009).

The improvement in plasma lipid profile, oxidative stress and testosterone levels in rats fed the hypercholesterolemic diet and given extract mixture I or II may be attributed to the presence of tocopherols, phytosterols, unsaturated fatty acids and phenolic compounds determined in the present study in addition to the carotenoids reported previously to be present in carrot and tomato.

Rice bran oil and wheat germ oil present in the two studied mixtures have been previously shown to contain high levels of tocopherols (Ardiansyah et al., 2006; Wang and Johnson, 2001) which render them antioxidant activity and thereby they may be capable of reducing lipid peroxidation and work as antioxidant for superoxide, singlet oxygen and peroxyl free radicals (Mayes, 1996). Rice bran oil contains an array of bioactive phytochemicals of antioxidant activity such as oryzanols, phytosterols, tocopherols, tocotrienols, and policosanols (Khatoon and Gopalakrishna, 2004; Ardiansyah et al., 2006). It was reported that rice bran oil possess hypocholesterolemic properties primarily attributable to its balanced fatty acid composition and high levels of the antioxidant phytochemicals (Devi et al., 2007). Orzynol has a greater effect on lowering plasma LDL-cholesterol levels and raising plasma HDL-cholesterol possibly through increasing the fecal excretion of cholesterol and its metabolites (Wilson 
et al., 2007). Wheat germ oil has been reported to contain phytosetrol, unsaturated fatty acids and oryzanol which collectively possess lipid lowering and antioxidant effects (Rustan et al., 1993).

The improvement in the plasma lipid profile due to the oral administration of mixtures I and II may be also due to the presence of phytosterols. Phytosterols, in various forms, have been shown to lower LDLcholesterol equivalently in hypercholesterolemic subjects by suppressing cholesterol absorption (Vanstone et al., 2002). Alhassan et al. (2006) reported that the addition of plant sterols into the diet inhibited cholesterol absorption and lowered serum cholesterol. Also a single morning dose of plant sterol (1.0-1.8 $\mathrm{g} / \mathrm{d})$ increased the plasma HDLcholesterol concentration by approximately $8 \%$ (Abu Mweis et al., 2006). The intake of plant sterols has been shown to confer a healthier lipid profile and ameliorate cardiovascular disease risk factors (Ziv et al., 2009). The intake of $2 \mathrm{~g}$ plant sterols/d in yoghurt had beneficial effects on the lipid profile of mildly hypercholesterolemic Indian adults and showed a $4.5 \%$ reduction in LDL-cholesterol and a $15 \%$ reduction in triglycerides (Khandelwal et al., 2009).

Both extract mixtures used in the present study are rich in oleic acid, which previously showed benefits on early events in atherosclerosis (Carluccio et al., 1999). Tsimikas et al. (1999) explained the mechanism by which oleic acidenriched diets decreased lipoprotein susceptibility to oxidation, presumably, as a result of the decreased linoleic acid content within lipoproteins. Studies on endothelial cells in vitro have shown that dietary oleic acid may prevent endothelium activation either by inhibiting the expression of adhesion molecules or by affecting nitric oxide production (Christon, 2003). Supplementation of endothelial cells with oleic acid in vitro reduces endothelial cell sensitivity to oxidants, creating a reduced prooxidant environment as a consequence of reduced intracellular ROS (Spolarics, 1996).

Carrot and tomato acetone extracts in the studied mixture are good sources of carotenoids, especially $\beta$-carotene and lycopene, respectively, which were reported previously to possess antioxidant and hypocholesterolemic effects (Fuhrman et al., 1997; Elson et al., 1999). Lycopene and $\beta$-carotene augmented the activity of the macrophage LDL receptor (Fuhrman et al., 1997). Also tomato contains esculeoside $A$, a new glycoside, which was identified from tomato with contents 4 times higher than lycopene (Fujiwara et al., 2004). The oral administration of esculeoside A to apoEdeficient mice significantly reduced the levels of serum cholesterol, triglycerides, LDL-cholesterol, and the areas of atherosclerotic lesions without any detectable side effects (Fujiwara et al., 2007). Epidemiological studies suggest that a diet rich in carotenoids is associated with a reduced risk of heart disease and cancer (Melendez-Martinez et al., 2004). Harari et al. (2008) suggested that 9-cis $\mathrm{b}$-carotene have the potential to inhibit atherogenesis in humans via its conversion to 9-cis retinoic acid, a ligand of the nuclear receptor Rexinoid $X$ Receptor (RXR). Several studies indicated that $\mathrm{RXR}$ and its heterodimers have the potential to reduce atherosclerosis by affecting lipid metabolism (Chinetti et al., 2001), cell migration (Day et al., 2006), apoptosis (Ji et al., 2001) and inflammation (Marx et al., 1999).

The reduction in oxidative stress and improvement in plasma lipid profile due to oral administration of mixtures I and II may be also ascribed to the presence of phenolic compounds in the crude methanol extract of thyme and celery seeds. Phenolic compounds are composed of several classes including flavonoids, anthocyanins, phenolic acids and catechins that are characterized by cyclic rings with hydroxyl substitutions at various positions (Duthie et al., 2000) which react readily with free radicals thereby preventing cell damage. Phenolic compounds have been reported to have antioxidant, anti-inflammatory and hypocholesterolemic activity (Löliger, 1991). Celery seeds showed antioxidant and cyclooxygenase inhibitory activity reflecting anti-inflammatory effects due to the presence of the phenolic compounds sedanolide and senkyunolide- $N$ (Momin and Nair, 2002). Also the methanol extract of celery seeds showed significant anti-gout activity in vivo, which usually involves high oxidative stress and inflammation (Mohamed and Al-Okbi, 2008). It was reported that long-term dietary intake of thyme in C57BL/6 mice impaired platelet functions in vitro and thrombus formations in vivo, while bleeding times were not affected. The mechanism of the antithrombotic effect may involve the suppression of platelet reactivity and the stimulation of the vascular endothelium (Naemura et al., 2008). Flavanoids were shown to markedly reduce platelet deposition, mural thrombi, and injury-induced vasoconstriction after deep arterial injury (Mruk et al., 2000). Flavonoids may prevent the adhesion of monocytes in the inflammatory process of atherosclerosis, thereby having health benefits in cardiovascular disease. Flavonoid has been reported to offer protection against cardiovascular disease, such as coronary heart disease (Goldberg et al., 1995).

From the present results, it can be suggested that the reduction of testosterone levels and increased T-Ch/HDL-Ch, TG/HDL-Ch and oxidative stress in hypercholesterolemic rats could be responsible for atherosclerosis and cardiovascular diseases. $A$ reduction in the incidence of CVD through ameliorating the aforementioned criteria has been achieved by the oral administration of mixture I or II.

\section{CONCLUSION}

The tested extract mixtures showed an improvement in plasma lipid profile, a significant increase in testosterone and a decrease in oxidative stress with promising prevention of atherosclerosis and cardiovascular diseases through a reduction in plasma $\mathrm{T}-\mathrm{Ch} / \mathrm{HDL}-\mathrm{Ch}$ and $\mathrm{TG} / \mathrm{HDL}-\mathrm{Ch}$ ratios and an increase in plasma testosterone levels. The anti- 
atherogenic effect of the extract mixtures may be due to the presence of phenolic compounds, phytosterols, tocopherols and unsaturated fatty acids. The studied mixtures showed complete safety towards liver and kidney functions.

\section{REFERENCES}

AbuMweis SS, Vanstone CA, Ebine N, Kassis A, Ausman LM, Jones PJ, Lichtenstein AH. 2006. Intake of a single morning dose of standard and novel plant sterol preparations for 4 weeks does not dramatically affect plasma lipid concentrations in humans. J. Nutr. 136, 1012-6.

Alhassan S, Reese KA, Mahurin J, Plaisance EP, Hilson BD, Garner JC, Wee SO, Grandjean PW. 2006. Blood lipid responses to plant stanol ester supplementation and aerobic exercise training. Metabolism 55, 541-9.

Amaral JS, Casal S, Torres D, Seabra RM, Oliveira BP. 2005. Simultaneous determination of tocopherols and tocotrienols in hazelnuts by a normal phase liquid chromatographic method. Analytical Sciences 21, 1545-1548.

AOAC. 1995. Official Methods of Analysis (15 $5^{\text {th }}$ ed.). (Association of Official Agricultural Chemists, Gaithersburg, MD).

A.O.A.C. 2000. Official Methods of Analysis (1 $17^{\text {th }}$ ed.). (Association of Official Agricultural Chemists, Gaithersburg, MD).

Ardiansyah SH, Koseki T, Ohinata K, Hazhizume K, Komai M. 2006. Rice bran fractions improve blood pressure, lipid profile, and glucose metabolism in stroke-prone spontaneously hypertensive rats. Journal of Agricultural and Food Chemistry 54, 1914-1920.

Augusti KT, Narayanan A, Pillai LS, Ebrahim RS, Sivadasan R, Sindhu KR. 2001. Beneficial effects of garlic (Allium sativum Linn) on rats feed with diets containing cholesterol and either of the oil seeds, coconuts or groundnuts. Indian J. Exp. Biol. 39, 660-7.

Briggs GM, Williams MA. 1963. A new mineral mixture for experimental rat diets and evaluation of other mineral mixtures. Fed. Proc. 22, 261-266.

Burstein M, Scholnick HR, Morfin R. 1980. Rapid method for the isolation of lipoproteins from human serum by precipitation with polyanions. Scand. J. Clin. Lab. Invest. 40, 583-595.

Carluccio MA, Massaro M, Bonfrate C, Siculella L, Maffia M, Nicolardi G, Distante A, Storelli C, De Caterina R. 1999. Oleic acid inhibits endothelial activation: direct vascular antiatherogenic mechanism of a nutritional component in the Mediterranean diet. Arterioscler Thromb. Vasc. Biol. 19, 220-8.

Chinetti G, Lestavel S, Bocher V, Remaley AT, Neve B, Torra IP, Teissier E, Minnich A, Jaye M, Duverger N, Brewer HB, Fruchart JC, Clavey V, Staels B. 2001. PPAR-alpha and PPAR-gamma activators induce cholesterol removal from human macrophage foam cells through stimulation of the ABCA1 pathway. Nat. Med. 7, 53-8.

Christon RA. 2003. Mechanisms of action of dietary fatty acids in regulating the activation of vascular endothelial cells during atherogenesis. Nutr. Rev. 61, 272-9.

da Luz PL, Favarato D, Faria-Neto JR Jr, Lemos P, Chagas AC. 2008. High ratio of triglycerides to HDLcholesterol predicts extensive coronary disease. Clinics (Sao Paulo). 63, 427-32.
Dauchet L, Amouyel P, Dallongeville J. 2009. Fruits, vegetables and coronary heart disease. Nat. Rev. Cardiol. 6, 599-608.

Day RM, Lee YH, Park AM, Suzuki YJ. 2006. Retinoic acid inhibits airway smooth muscle cell migration. Am. J. Respir. Cell Mol Biol. 34, 695-703.

de Jong A, Plat J, Ltjohann D, Mensink RP. 2008. Effects of long-term plant sterol or stanol ester consumption on lipid and lipoprotein metabolism in subjects on statin treatment. Br. J. Nutr. 100, 937-41.

Desia I.D, Machlin LJ. 1985. Vitamin E. In: Methods of Vitamin Assay. (eds. J. Augustin, B.P. Klein, D. Becker, P.B. Venugopal). $4^{\text {th }}$ edition. A widely Interscience Publication John Wiley and Sons, New York, p. 255-275.

Devi R, Jayalekshmy A, Arumughan C. 2007. Antioxidant efficacy of phytochemical extracts from defatted rice bran in the bulk oil system. Food Chemistry 104, 658-664.

Duthie GG, Duthie SJ, Kyle JAM. 2000. Plant polyphenols in cancer and heart disease: Implications as nutritional antioxidants. Nutr. Res. Rev. 13, 79-106.

Elson CE, Peffley DM, Hentosh P, Mo H. 1999. Isoprenoidmediated inhibition of mevalonate synthesis: potential application to cancer. Proc. Soc. Exp. Biol. Med. 22, 294-310.

Fawcett JK, Scott JE. 1960. A rapid and precise method for the determination of urea. J. Clin. Pathol. 13, 156159.

Fernández-Robredo $P$, Rodriguez JA, Sádaba LM, Recalde S, Garcia-Layana A. 2008. Egg Yolk improves lipid profile, lipid peroxidation and retinal abnormalities in a murine model of genetic hypercholesterolemia. $J$. Nutr. Biochem. 19, 40-48.

Fuhrman B, Elis A, Aviram M. 1997. Hypocholesterolemic effect of lycopene and $\beta$-carotene is related to suppression of cholesterol synthesis and augmentation of LDL receptor activity in macrophages. Biochem Biophys Res. Commun. 233, 658-662.

Fujiwara Y, Takaki A, Uehara Y, Ikeda T, Okawa M, Yamauch K, Ono M, Yoshimitsu H, Nohara T. 2004. Tomato steroidal alkaloid glycosides, esculeoside A and B, from ripe fruits. Tetrahedron 60, 4915- 4920.

Fujiwara Y, Kiyota N, Hori M, Matsushita S, lijima Y, Aoki K, Shibata D, Takeya M, Ikeda T, Nohara T, Nagai R. 2007. Esculeogenin A, a New Tomato Sapogenol, Ameliorates Hyperlipidemia and Atherosclerosis in ApoE-Deficient Mice by Inhibiting ACAT. Arterioscler Thromb. Vasc. Biol. 27, 2400-2406.

Gerard T, Gerald AL. 1981. Process and reagents for the selective separation of low density lipoprotein (LDL) and for the quantification of their components. Eur. Path. (Appl.) E.P. 76, 211-223.

Gokkusu C, Mostafazadeh T. 2003. Changes of oxidative stress in various tissues by long-term administration of vitamin E in hypercholesterolemic rats. Clin. Chim. Acta 328, 155-161.

Goldberg DM, Hahn SE, Parkes J.G. 1995. Beyond alcohol: Beverage consumption and cardiovascular mortality. Clin. Chim. Acta 237, 155-87.

Granner DK. 1996. Hormones of the adrenal cortex. In: "Harper's biochemistry". Ed. Murray RK, Granner Dk, Rodwell VW, 24 ${ }^{\text {th }}$ edition, Appleton and Lange, Los Altos, California, p. 547-559.

Guo F, Xu CJ. 2005. Progress on the study of mechanism of the direct action of TCM bioactive components on ovarian cancer. Zhongguo Zhong Xi Yi Jie He Za Zhi 25, $1140-4$. 
Gutteridge JMC, Halliwell B. 2000. Free radicals and antioxidants in the year 2000: a historical look to the future. Annals of the New York Academy of Sciences. 899, 136-147.

Harari A, Harats D, Marko D, Cohen H, Barshack I, Kamari Y, Gonen A, Gerber Y, Ben-Amotz A, Shaish A. 2008. A 9-cis $\beta$-Carotene-Enriched Diet Inhibits Atherogenesis and Fatty Liver Formation in LDL Receptor Knockout Mice. J. Nutr. 138, 1923-1930.

Houot O. 1985. Interpretation of clinical laboratory tests. Edit. Siest G, Henny J, Schiele F, Young D S. Biomedical publications.

Ji JD, Cheon H, Jun JB, Choi SJ, Kim YR, Lee YH, Kim TH, Chae IJ, Song GG, Yoo DH. 2001. Effects of peroxisome proliferator-activated receptorgamma (PPAR-gamma) on the expression of inflammatory cytokines and apoptosis induction in rheumatoid synovial fibroblasts and monocytes. J. Autoimmun 17, 215-21.

Kaliora AC, Dedoussis GV. 2007. Natural antioxidant compounds in risk factors for CVD. Pharmacological Research 56, 99-109.

Khandelwal S, Demonty I, Jeemon P, Lakshmy R, Mukherjee R, Gupta R, Snehi U, Niveditha D, Singh Y, van der Knaap HC, Passi SJ, Prabhakaran D, Reddy KS. 2009. Independent and interactive effects of plant sterols and fish oil n-3 long-chain polyunsaturated fatty acids on the plasma lipid profile of mildly hyperlipidaemic Indian adults. Br. J. Nutr. 102, 722-32.

Khatoon S, Gopalakrishna AG. 2004. Fat-soluble nutraceuticals and fatty acid composition of selected Indian rice varieties. Journal of the American Oil Chemists' Society 81, 939-943.

Koch TC, Goldman IL. 2005. Relationship of carotenoids and tocopherols in a sample of carrot root-color accessions and carrot germplasm carrying $\mathrm{Rp}$ and $\mathrm{rp}$ alleles. J. Agric. Food Chem. 53, 325-31.

Kris-Etherton PM, Hecker KD, Bonamone A, Coval SM, Binkoski AE, Hilpert KF. 2002. Bioactive compounds in foods: their role in the prevention of cardiovascular disease and cancer. Am. J. of Med. 113, 71-88.

Löliger J. 1991. The use of antioxidants in food. In: Free radicals and food additives. Aruoma OI., Halliwell B. Eds. Taylor and Francis, London, pp. 129-138.

Marx N, Sukhova GK, Collins T, Libby P, Plutzky J. 1999. PPARalpha activators inhibit cytokine-induced vascular cell adhesion molecule- 1 expression in human endothelial cells. Circulation 99, 3125-31.

Mayes PA. 1996. Structure and function of the lipidsoluble vitamins. In "Harper's Biochemistry" Edit. Murray RK, Granner DK, Mayes PA, Rodwell VW. $23^{\text {rd }}$ edition, Appleton and Lange, California. p. 614.

Megraw R, Dunn D, Biggs H. 1979 Manual and continuous flow colorimetry of triglycerols by a fully enzymatic method. Clin. Chem. 25, 273-284.

Melendez-Martinez AJ, Vicario IM, Heredia FJ. 2004. Nutritional importance of carotenoid pigments. Arch. Latinoam. Nutr. 54,149-54.

Mirmiran P, Noori N, Zavareh MB, Azizi F. 2009. Fruit and vegetable consumption and risk factors for cardiovascular disease. Metabolism 58, 460-8.

Mohamed DA, Al-Okbi SY. 2008 Evaluation of anti-gout activity of some plant foods. Pol. J. Food Nutr. Sci. 58, 389-395.

Momin RA, Nair MG. 2002. Antioxidant, cyclooxygenase and topoisomerase inhibitory compounds from Apium graveolens Linn. seeds. Phytomedicine 9, 312-8.
Morcos SR. 1967 The effect of protein value of the diet on the neurological manifestations produced in rats by $\beta$-immodipropionitrile. Br. J. Nutr. 21, 269-274.

Mruk JS, Webster MW, Heras M, Reid JM, Grill DE, Chesebro JH. 2000. Flavone-8-acetic acid (Flavonoid) profoundly reduces platelet-dependent thrombosis and vasoconstriction after deep arterial injury In vivo. Circulation 101, 324-8.

Naemura A, Ura M, Yamashita T, Arai R, Yamamoto J. 2008. Long-term intake of rosemary and common thyme herbs inhibits experimental thrombosis without prolongation of bleeding time. Thrombosis Research 122, 517-522.

Neeld JB, Pearson WN. 1963. Macro and micro methods for the determination of serum vitamin A using trifluroacetic acid. J. Nutr. 79, 454-462.

Nicolle C, Cardinault N, Gueux E, Jaffrelo L, Rock E, Mazur A, Amouroux P, Rémésy C. 2004. Health effect of vegetable-based diet: lettuce consumption improves cholesterol metabolism and antioxidant status in the rat. Clin. Nutr. 23, 605-614.

Olshansky SJ, Passaro DJ, Hershow RC. 2005. A potential decline in life expectancy in the United States in the 21st century. N. Engl. J. Med. 352, 1138-1145.

Pace-Asciak CR, Hahn S, Diamandis EP, Soleas G, Goldberg DM. 1995. The red wine phenolics transresveratrol and quercetin block human platelet aggregation and eicosanoid synthesis: Implications for protection against coronary heart disease. Clin. Chim. Acta 237, 207-219.

Pellegrini N, Serafini M, Colombi B, Del Rio D, Salvatore S, Bianchi M. 2003. Total antioxidant capacity of plant foods, beverages, and oils consumed in Italy assessed by three different in vitro assays. J. Nutr. 133, 2812-2819.

Poli A, Marangoni F, Paoletti R, Mannarino E, Graziana Lupattelli B, Notarbartolo A, Aureli P, Bernini F, Cicero A, Gaddi A, Catapano A, Cricelli C, Gattone M, Marrocco W, Porrini M, Stella R, Vanotti A Volpe M. 2008. Non-pharmacological control of plasma cholesterol levels. Nutrition, Metabolism and Cardiovascular Diseases 18, S1-S16.

Ramirez TMA, Carrera A, Zambrana M. 2000. High incidence of hyperestrogenemia and dyslipidemia in a group of infertile men. Gynecol Obstet Mex 68, 224-9.

Reitman S, Frankel S. 1957 Colorimetric methods for aspartate and alanine aminotransferase. Am. J. Clin. Path. 28, 55-60.

Rosano GM, Cornoldi A, Fini M. 2005. Effects of androgens on the cardiovascular system. 28, 32-8.

Rosano GM, Sheiban I, Massaro R, Pagnotta P, Marazzi G, Vitale C, Mercuro G, Volterrani M, Aversa A, Fini M. 2007. Low testosterone levels are associated with coronary artery disease in male patients with angina. Int. J. Impot Res. 19,176-82.

Rustan I., Damiano M.M., Lergards G. 1993. Mise au point de la recherche d'antioxydants a usage alimentaire et applications, Falsif. Expert. Chim. Toxicol. 86, 201.

Saad F, Gooren L. 2009. The role of testosterone in the metabolic syndrome: a review. J. Steroid Biochem Mol. Biol. 114, 40-3.

Saito M, Yamauch Y. 1990. Isolation of tocopherols from wheat germ oil by recycle semi preparative supercritical fluid chromatography. J. Chromatogr. 505, 257-271.

Saito M, Ikushima Y, Hatakeda K, Ito S, GotoT. 1993. Fractional extraction of rice bran oil and its esters with supercritical carbodioxide. Int. Chem. Eng. 33, 307-314 
Satoh K. 1978. Serum lipid peroxide in cerebrovascular disorders determined by a new colorimetric method. Clinica Chimica Acta. 20, 37-43.

Schubert M, Jockenhövel F. 2010. Testosterone and the metabolic syndrome. Urologe A. 49, 47-50.

Shah S, Iqbal M, Karam J, Salifu M, Mcfarlane SI. 2007. Oxidative stress, glucose metabolism and the prevention of type 2 diabetes: pathophyiological insights. Antioxidants and redox signaling. 9, 911-929.

Singleton VL, Rossi JA. 1965. Colorimetry of total phenolics with phosphomolybdic-phosphotungstic acid reagents. Am. J. Enol. Vitic. 16, 144-158.

Son S, Lewis BA. 2002. Free radical scavenging and antioxidative activity of caffeic acid amide and ester analogues: structure-activity relationship. J. Agric. Food Chem. 30, 468-472.

Spolarics Z. 1996. Endotoxin stimulates gene expression of ROS eliminating pathways in rat hepatic endothelial and Kupffer cells. Am. J. Physiol. 270, 660-6.

Stanner SA, Hughes J, Kelly CN, Buttriss J. 2004 A review of the epidemiological evidence for the 'antioxidant hypothesis'. Public Health Nutrition 7. 407-422.

Thomas S, Rich MW. 2007. Epidemiolgy, pathophysiology, and prognosis of heart failure in the elderly. Clin. Geriatr. Med. 23, 1-10.

Thorand B, Baumert J, Chambless L, Meisinger C, Kobb $\mathrm{H}$, Doring A. 2006. For the MONICA/KORA study group. Elevated markers of endothelial dysfunction predict type 2 diabetes mellitus in middle-aged men and women from the general population. Arterioscler Thromb. Vasc. Biol. 26, 398-405.

Tietz NW. 1995. Clinical guide to laboratory tests, $3^{\text {rd }}$ edition, W. B. Saunders, Co., Philadelphia. pp 578580.

Toro G, Ackerman PG. 1975. Practical Clinical Chemistry $1^{\text {st }}$ edition, Little, Brown and Company, Boston USA, pp.352-359.

Traish AM, Abdou R, Kypreos KE. 2009. Androgen deficiency and atherosclerosis: The lipid link. Vascul. Pharmacol. 51, 303-13.
Tsimikas S, Philis-Tsimikas A, Alexopoulos S, Sigari F, Lee C, Reaven PD. 1999. LDL isolated from Greek subjects on a typical diet or from American subjects on an oleatesupplemented diet induces less monocyte chemotaxis and adhesion when exposed to oxidative stress. Arterioscler Thromb Vasc. Biol. 19,122-30.

Vanstone CA, Raeini-Sarjaz M, Parsons WE, Jones PJ. 2002. Unesterified plant sterols and stanols lower LDL-cholesterol concentrations equivalently in hypercholesterolemic persons. Am. J. Clin. Nutr. 76, 1272-1278.

Wang T, Johnson LA. 2001. Refining high-free fatty acid wheat germ oil. JAOCS. 78, 71-76.

Watson D.1960. A simple method for the determination of serum cholesterol. Clin. Chem. Acta. 5, 637-642.

Wilson TA, Nicolosi RJ, Woolfrey B, Kritchevsky D. 2007. Rice bran oil and oryzanol reduce plasma lipid and lipoprotein cholesterol concentrations and aortic cholesterol ester accumulation to a greater extent than ferulic acid in hypercholesterolemic hamsters. $J$. Nutr. Biochem. 18, 105-112.

Yang R, Le G, Li A, Zheng J, Shi Y. 2006. Effect of antioxidant capacity on blood lipid metabolism and lipoprotein lipase capacity of rats feed a high-fat diet. Nutr. 22, 1185-1191.

Young IS, Woodside JV. 2001. Antioxidants in health and disease. J. Clin. Pathol. 54, 176-186.

Ziv E, Patlas N, Kalman R, Pelled D, Herzog Y, Dror T, Cohen T. 2009. A high oleic sunflower oil fatty acid esters of plant sterols mixed with dietary diacylglycerol reduces plasma insulin and body fat accumulation in Psammomys obesus. Lipids Health Dis. 12, 42.

Zulet M.A., Macarulla M.T., Portillo M.P., Noel-Suberville C., Higueret P., Matinez J.A. (1999): Lipid and glucose utilization in hypercholesterolemic rats fed a diet containing heated chickpea (Cicer Aretinum L.): a potential functional food. Int. J. Vitam. Nutr. Res. 69, 403-409.

Recibido: $4 / 2 / 10$ Aceptado: $15 / 3 / 10$ 